УДК 796(438)«1945/1950»

\title{
DETERMINANTS OF THE EVOLUTION OF PHYSICAL CULTURE IN THE KOSZALIN REGION IN 1945-1950
}

\author{
Agnieszka Polaniecka ${ }^{1}$, Anna Błaszkowska²
}

\author{
${ }^{1}$ State Higher Vocational School in Koszalin, Poland, polaniecka@onet.eu \\ ${ }^{2}$ Nicolaus Copernicus University in Torun, Faculty of Political Science and International Studies, Poland, \\ blaszkowska.ann@gmail.com
}

https://doi.org/10.29038/2220-7481-2019-04-38-45

\begin{abstract}
s
In the first post-war years, in the Koszalin region there was a multi-million migration related to the settlement of the so-called Recovered Territories. Rapid development and settlement of the largest number of Poles in the area became one of the most important tasks after the end of hostilities. It should be noted that the population that came to the so-called The Recovered Territories, built from scratch, living conditions and certain areas of social life, including cultural and sporting life. Among the settlers who arrived in Koszalin, there were pre-war sports activists, players, members of associations and clubs who, apart from professional activities, took up the organization of sport. In a new, uneasy situation, Poles' environments organized their cultural and sporting lives without closing to the emerging and mixed communities. The first organizational units of physical culture in Central Pomerania were sports clubs, which primarily formed at selected professional groups, the most active were groups of railwaymen, militiamen and craftsmen. Sport in this area was more than just competition or «fun for the body and soul», it also served to integrate the settled population. This applied not only to rivals competing with each other, but also fans watching sporting events, which became a way of spending time and an opportunity to celebrate together. Not only, however, they also influenced the formation of social bonds. Cooperative works for the development of sport formed the foundation of a new social life.
\end{abstract}

Key words: physical culture, sport, Koszalin region, Recovered Territories.

Агнешка Пованєцка, Анна Блашковська. Визначення еволюції фізичної культури в Кошалінському регіоні в 1945-1950 pp. У перші повоєнні роки в Кошалінському регіоні відбулася багатомільйонна міграція, пов'язана 3 заселенням так званих відновлених територій. Бурхливий розвиток та заселення найбільшої кількості поляків у районі стало одним із найважливіших завдань після закінчення бойових дій. Слід зазначити, що населення, яке потрапило на так звані відроджені території, побудовало з нуля побутові умови та певні сфери суспільного життя, уключаючи культурне та спортивне життя. Серед переселенців, які прибули до Кошаліна, були активісти передвоєнного спорту, гравці, члени асоціацій та клубів, які, окрім професійної діяльності, займались організацією спорту. У новій, непростій ситуації середовище поляків організовувало своє культурне та спортивне життя, не ізолюючись від нових та змішаних громад. Першими організаційними підрозділами фізичної культури в Центральній Померанії були спортивні клуби, які, передусім, формувались у вибраних професійних колективах. Найактивнішими були групи залізничників, міліціонерів та майстрів. Спорт у цій галузі був більше, ніж просто змаганням або «розвагою для тіла та душі», він також слугував інтеграцією осілого населення. Це стосувалося не лише конкурентів, які змагаються один з одним, але й шанувальників, які спостерігали за спортивними подіями, що стало способом проведення часу та можливістю святкувати разом. Однак вони не тільки вплинули на формування соціальних зв'язків. Кооперативні роботи з розвитку спорту лягли в основу нового суспільного життя.

Ключові слова: фізична культура, спорт, Кошалінський край, відновлені території.

Агнешка Пованецка, Анна Блашковська. Определение эволюции физической культуры в Кошалинском регионе в 1945-1950 годах. В первые послевоенные годы в Кошалинском регионе состоялась многомиллионная миграция, связанная с заселением так называемых восстановленных территорий. Бурное развитие и заселение наибольшего количества поляков в районе стало одной из важнейших задач после окончания боевых действий. Следует отметить, что население, которое попало на так называемые возрожденные территории, построело с нуля, бытовые условия и определенные сферы общественной жизни, включая культурную и спортивную жизнь. Среди переселенцев, прибывших в Кошалин, были активисты предвоенного спорта, игроки, члены ассоциаций и клубов, которые, кроме профессиональной деятельности, занимались организацией спорта. В новой, непростой ситуации среда поляков организовывала свою культурную и спортивную жизнь, не изолируясь от новых и смешанных общин. Первыми организационными подразделениями физической культуры в Центральной Померании были спортивные клубы, которые, в первую очередь, формировались в выбранных профессиональных коллективах. Самыми активными были группы железнодорожников, милиционеров и мастеров. Спорт в этой области был больше, чем просто соревнованием или «развлечением 
для тела и души», он также служил интеграцией оседлого населения. Это касалось не только конкурентов, которые соревнуются друг с другом, но и поклонников, которые наблюдали за спортивными событиями, для них это стало способом времяпрепровождения и возможностью праздновать вместе. Однако они не только повлияли на формирование социальных связей. Кооперативные работы по развитию спорта легли в основу новой общественной жизни.

Ключевые слова: физическая культура, спорт, Кошалинский край, восстановленные территории.

Introduction. The research topic on the determinants of the evolution of physical culture in the Koszalin region in 1945-1950 has been partly presented, among others in the publications of Jerzy Gaj, Marian Górecki, Tomasz Jurek, Władysław Kujawa, Jerzy Krzysztofowicz, Marek Szczerbiński, Bernard Woltmann - Physical Culture in the Koszalin region 1945-1989 and Physical Culture in the Koszalin region 1945-1990, in the dissertation of Jerzy Krzysztofowicz - Outline of History physical culture in the Koszalin Province in 19451975. It should be noted, however, that the listed items illustrate the process of shaping physical culture in the Koszalin region after 1945 as one of many areas studied.

Therefore, the article analyzes the role of physical culture in the development of the Koszalin region. Archival data, published and unpublished works were used to accurately and comprehensively present the processes occurring in physical culture after 1945 in the discussed area.

In accordance with the principles of historical research methodology, the author analyzed historical sources and available literature and query library resources, then thoroughly evaluated them in terms of suitability for further research, used synthesis, induction, deduction and a comparative method.

As a result of the research, a significant role of sport activity and competition was observed in the development of physical culture as an element of social and cultural life of the Koszalin region.

\section{Historical Outline of the Koszalin Region}

In the nineteenth century, the area of Central Pomerania was inhabited primarily by Germans. The Polish population on the northeastern border of the German Reich numbered about 21,000 people. The Złotów district was the main center of Polishness in the Poznan-West-Prussian Border Monarchy. Small groups of the Polish population were located in the Piła region ${ }^{1}$ and in the Bytów province.

In the first post-war years, there was a multi-million migration in these areas ${ }^{2}$, associated with the settlement of the so-called Recovered Territories, awarded to Poland during the conference in Yalta on February 4-11, 1945. Special role for the settlement and development of these lands was played by the Ministry of Recovered Territories established in 1945 and the state, social and military institutions cooperating with it ${ }^{3}$. A special commission was also created to develop the principles of organizing local administration, the so-called Recovered Territories and the commencement of completing operational groups of railwaymen, postal workers and employees of the State Repatriation Office ${ }^{4}$. Western Pomerania together with the Lubusz Land formed the III Administrative District of the so-called Recovered Territories, to which the following districts belonged: Szczecin, Koszalin, Bytów, Słupsk, Sławno, Człuchów, Miastko and Złotów provinces 5 .

As a result of hostilities, the areas in question were significantly damaged, but not all towns to the same extent, Kołobrzeg in almost $90 \%$, Koszalin in $80 \%$, while in Białogard just one building burned down (as a result of information provided to the Soviet soldiers that Germans were hiding there), thanks to which the city had a good housing base, which was allocated to arriving migrants ${ }^{6}$.

\footnotetext{
${ }^{1}$ Woltmann B.: Basics of physical culture development in the Koszalin region. [in:] the same (ed.): Physical culture in the Koszalin region 1945-1990. Koszalin, 1993. P. 9.

${ }^{2}$ After the end of hostilities, the newly formed Polish socialist state lost its territory for the so-called Curzon Line. The country was in a difficult political and economic situation. In reviving Poland, leftist groups have begun to implement change despite problems in communication between the allies of the Grand Coalition. The Polish Workers' Party, supported by the Moscow regime, took over a leading role in the country. The coming to power of the representatives of this political force changed the nature of government governance. J. Gaj: Changes and determinants of physical culture in Poland. [in:] B. Woltmann (ed.) Physical culture in the Koszalin region 1945-1989. Koszalin, 1991. P. 20.

${ }^{3}$ Górecki M. The beginnings of post-war physical culture in the Szczecin voivodship in 1945-1950. [in:] B. Woltmann (ed.) Physical culture in the Koszalin region 1945-1989. Koszalin, 1991. P. 64.

${ }^{4}$ Szwajca K. Koszalin lands. Artistic and Graphic Publishing House. Krakow, 1975. P. 10.

${ }^{5}$ Czarnik A. Koszalińskie - Development of the voivodship in People's Poland. Warsaw: PWN, 1970. P. 10.

${ }^{6}$ Account of A. Krzemiński, resident in Koszalin, from 31.07.2019. Adam Krzemiński - born on 30. 10.2019 in Lviv. The Krzemiński family lived in the town of Buczacz Tarnopolskie, mother was a master's degree in law, father a lawyer, in February 1940 the family was taken to Siberia to the Semipałatyn region, pupastok 3. In June 1946 they returned to Poland and settled in Białogard. Adam Krzemiński became an employee of PUWFiPW in Koszalin, then in 1951-1989 a basketball referee, including at the central level from 1955 to 1986. In 1986-2004 he was the commissioner of PZKosz, Honorary Judge of PZKosz. In the years 1956-1995 he was an active member of the OZKosz in Koszalin, secretary of the board at the College of Judges. The organizer of Tournaments for the Cup of
} 
They included, among others railwaymen seconded to the so-called Recovered Territories, there was a railway junction in Białogard. However, the first Poles who found themselves outside the German population after the liberation of the Koszalin region were recruited from a group of several thousand people forced to work for Germany and prisoners of war in this area. The part of them that decided to stay in this place initiated Polish settlement.

\section{The Process of Colonization of the Koszalin Land after the end of World War II}

In the first months after the end of hostilities, individual settlers from Central Poland ${ }^{7}$ also began to flow in. Migrants from Gniezno were the first to come to Koszalin ${ }^{8}$. There were also some conflicts happening in this area, because the immigrant population considered the locals as Germans, and the authorities did not keep up with verification and protective measures ${ }^{9}$.

Due to economic difficulties, the intended results were not achieved in the field of group settlement, and care and assistance in provinces was insufficient. The settlers felt the lack of equipment, livestock and farm buildings. Quick development of the so-called The Recovered Territories and the settlement of as many Poles as possible on them was one of the most important tasks in the first post-war years ${ }^{10}$.

The migrants who arrived in the area in question first needed to secure living conditions, therefore, first of all, they focused on the organization and reconstruction of their assigned homes. After six years of Nazi occupation and settling in new areas, they needed stability and «normality», therefore, despite the difficult situation, they organized their cultural and sporting lives without closing themselves to emerging mixed communities $^{11}$.

It was a favorable decision for the development of sport in the Koszalin region that from May 23, 1945 the Office of the Plenipotentiary and Government was located in Koszalin. In this way, Koszalin became the capital of the Western Pomerania District ${ }^{12}$. As a result, the formation of authorities, the concentration of socioeconomic activities temporarily caused a large influx of repatriates and specialist groups delegated here by the central provinces. This contributed to the grouping of a significant number of Polish troops and internal services, which favored lively sporting activities.

\section{Social Initiatives to Create a Sports Movement in the Koszalin Region}

It a significant fact that the settlers who included pre-war sports activists, players, members of associations and clubs, not only were dealing with their professional activities but also took up the organization of sport. This was essential for the creation of sport life. Together with activists and sportsmen from native population, they laid the foundations for post-war physical culture in the recovered territories ${ }^{13}$.

It should be noted that the process of shaping sport in the Koszalin region proceeded in a different way than in the rest of the country, there were no traditions of the Polish sports movement outside the Złotów and Bytów provinces, therefore this area of social life was created from scratch. This task was hampered by the lack of a base and sports staff. As a result of hostilities, sports and tourist equipment was destroyed, and the team of activists and sportsmen was decimated ${ }^{14}$. Often, gyms were used for purposes other than those intended, in connection with the situation as a result of social acts, attempts were made to rebuild destroyed stadiums and sports fields. Joint activities gathered a large group of sports fans. In this way, social acts also fulfilled integration functions among people coming from all parts of the country ${ }^{15}$.

the Baltic and Nadodrzan Lands in the men category. He was one of the most distinguished sports activists of the Koszalin Province.Decorated with: the Knight's Cross of the Order of Polonia Restituta, the Gold Cross of Merit for merits for the development of basketball, the Gold Honorary Badge of the PZKosz, as a Distinguished Activist of Physical Culture - gold, the Medal for Merit for the Development of Basketball PZKosz, the Medal of the 50th Anniversary of the PZKosz, the Medal of Honor Koszalin Province ", Honorary Badge" Distinguished for the city of Koszalin ". M. Dunst (ed.), 60 years of West Pomeranian basketball, ZAPOL Szczecin, 2006. P. 251.

${ }^{7}$ Szwajca K. Koszalin lands. Krakow, 1975. P. 2.

${ }^{8}$ Account of A. Krzemiński, resident in Koszalin.

${ }^{9}$ Górecki M. The beginnings of post-war physical culture in the Szczecin voivodship in 1945-1950. [in:] B. Woltmann (ed.). Physical culture in the Koszalin region 1945-1989. Koszalin, 1991. P. 64.

${ }^{10}$ Żytko T. Development of handball in the Koszalin voivodship in the years 1945-1975, Master's thesis at the Academy of Physical Education in Poznań, Branch in Gorzów Wlkp. Gorzów 1977. s.14,15; A. Czernik, Koszalińskie. Warsaw: PWN, 1970. P. 42.

${ }^{11}$ Górecki M. The beginnings of post-war physical culture in the Szczecin voivodship in 1945-1950. [in:] B. Woltmann (ed.) Physical culture in the Koszalin region 1945-1989. Koszalin, 1991. P. 64.

${ }^{12}$ Szwajca K. Koszalin lands. Artistic and Graphic Publishing House. Krakow, 1975. P. 10.

${ }^{13}$ Szczerbiński M. Activities of state and social organs of physical culture in the Koszalin Region 22-29. [in:] B. Woltmann (ed.), Physical culture in the Koszalin region 1945-1990. Koszalin, 1993. P. 22.

${ }^{14}$ Rybicki H., Jędrzejczak W. Koszalińskie in the 20 years of the PRL. Poznań, 1966. P. 313.

${ }^{15}$ Górecki M. The beginnings of post-war physical culture in the Szczecin voivodship in 1945-1950. [in:] B. Woltmann (ed.) Physical culture in the Koszalin region 1945-1989. Koszalin, 1991. P. 64. 
Participation in the organization of sport made it possible to create social bonds, friendships and joint actions in various roles - the organizer, fan and participant. Sport has always attracted many supporters, triggered emotions, relaxed, for many people it was a form of spending free time, escaping from everyday life, social integration, and a way of establishing relationships. According to A. Pawlak, sporting activities can be considered as testing throughout life and the sports movement as an «academy of social life» ${ }^{16}$. At every historical stage, the physical education system changes depending on the conditions that are created by the community. At the same time, humanity receives as a heritage those cultural values that arose at earlier stages of the historical development of society ${ }^{17}$.

In fact, reactivating sport in the Koszalin region after the war was the result of the work of enthusiasts, people associated with pre-war sport. After a break of several years, they organized sports events and recreated clubs.

\section{The First Sporting Events after the End of World War II}

Football was the most popular. According to the research carried out by Henryk Laskiewicz, based on the analysis of the development of sports disciplines, it could be concluded that the most numerous group of pioneers of sports in Western Pomerania since 1945 were football players. They were ahead of the representatives of other sports games, athletes and boxers ${ }^{18}$. In June 1945, the District Football Association was established with headquarters in Koszalin. However, at the beginning of 1946 it was transferred to Szczecin ${ }^{19}$.

Athletics was another sports activity that was highly popular - the queen of sport, so called because of the abundance of competition, among them unusual ones, which include cross-country and street running ${ }^{20}$.

The first sporting events organized in the Koszalin region were football matches and street running. In Koszalin, the Battyk sports club played a meeting with the Red Army team, and then with the national team of Gniezno. On the initiative of the Provincial Office of Physical Education and Military Preparation on May 1, 1947, the Great National Street Race took place in Koszalin on the route of $3 \mathrm{~km}$. The patronage over this event was taken by the regional Marshal, Edmund Dobrzycki ${ }^{21}$.

In Kołobrzeg, the local activists dared to initiate a modest initiative, a match for the society, that reverberated later on a large scale, in which the first sportsmen played - the first settlers trying their hand with soldiers of the Soviet army ${ }^{22}$. The first race was also organized, which was given the name of National Race ${ }^{23}$.

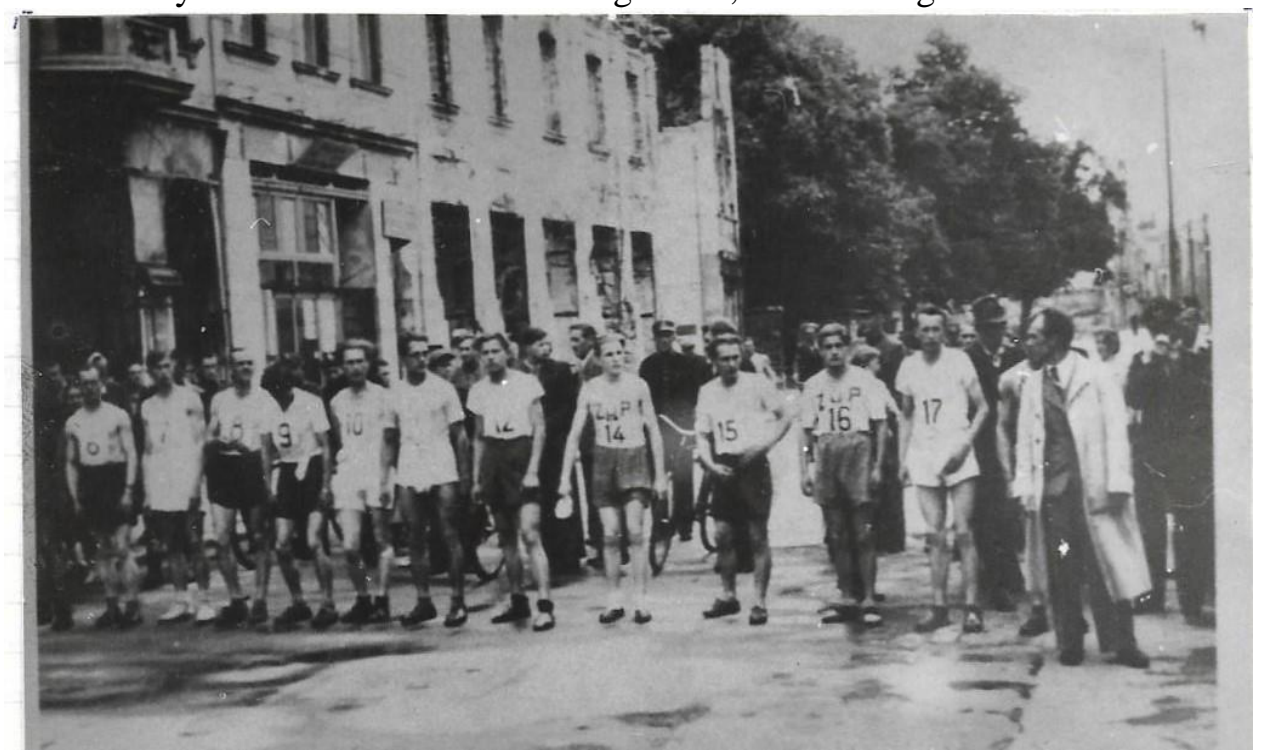

Photo 1. Competitors of the 1st National Race at the Start-Kolobrzeg.

Source: Z. Rutkowska, Development of Physical Culture in the Kolobrzeg Province in 1945-1956, Master's Thesis, Teachers' College in Kolobrzeg 1971. P. 11.

\footnotetext{
${ }^{16}$ Pawlak A. Status of Polish Olympians after the end of their sports careers. Warsaw, 1983. P. 193.

${ }^{17}$ Wilczkowski E., Pasicznik W. Establishment and development of physical education in Asian countries (on the example of China, India, Japan) [in:] (ed.) E. Małolepszy, Sport and Tourism Central European Journal of Science, T.2, NR 3. Częstochowa, 2019. P. 12.

${ }^{18}$ Laskiewicz H. Participation in the physical culture of the population of Western Pomerania. US Szczecin, 1990. P. 194.

${ }^{19}$ Laskiewicz H. Supra-local physical culture organizations in Western Pomerania (1945-1957). US Szczecin, 1996. P. 32.

${ }^{20}$ Połaniecka A. Słupsk Sport in the Słupsk Land (1975-1998). Gdańsk, 2017. P. 63.

${ }^{21}$ Szczerbiński M. Activities of state and social organs of physical culture in the Koszalin region. [in:] B. Woltmann (ed.), Physical culture in the Koszalin region 1945-1990. Koszalin, 1993. P. 23.

${ }^{22}$ Rutkowska Z. Development of physical culture in the Kołobrzeg poviat in 1945-1956, Master's thesis, Teacher training in Kołobrzeg 1971. P. 11.

${ }^{23}$ Ibid. P. 14.
} 


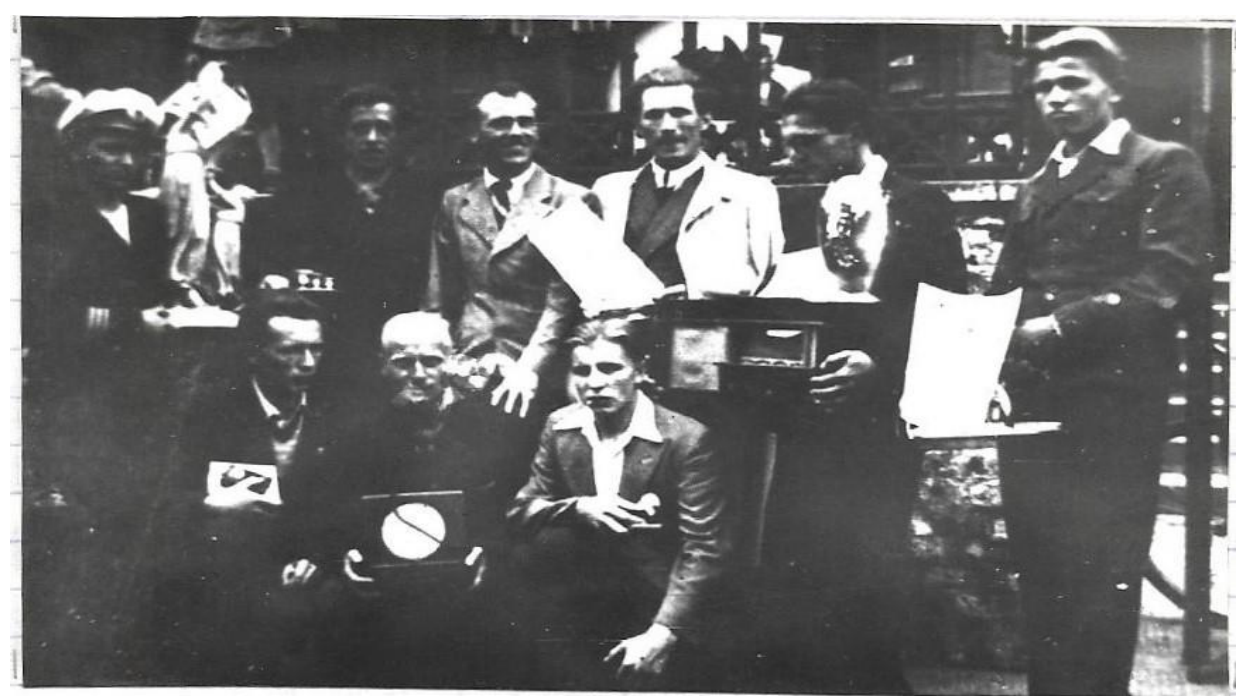

Photo 2. Winners of the 1st National Race, with the Prizes Received. Source: Z. Rutkowska, Development of Physical Culture in the Kołobrzeg Province in 1945-1956, Master's Thesis, Teachers' College in Kołobrzeg 1971. P. 14.

The first match between Polish players and the Soviet team took place in Slupsk, Zwycięstwa Square, that ended with a 2: 1 result for the Polish team. In the rematch, Soviet soldiers won 4: $3^{24}$.

In Szczecinek, a football match was played between the local Zetwuem team Zryw and the Koszalin team. The youngsters won, and after a week Zryw noted another success, winning a rematch in Koszalin ${ }^{25}$.

The Człuchów organization ZWM joined the sport organization very actively. From 1945 Sports Club Zryw, started the football and volleyball sections. At the marina, 25 rowing boats, sailboats and a motorboat were collected in Człuchów, encouraging young people to practice water sports. The club organized many events, especially on public holidays and anniversaries. There were street runs. Moreover, sports sections looked for partners outside the Province. A significant sporting event of the Koszalin region was organized on September 9, 1945 at the Koszalin Municipal Stadium during the Sports Festival and Harvest Festival on the occasion of the first crops. The harvest program included, among others, a football match between the teams of Koszalin and Poznan, shooting competitions, volleyball games for the Championship of West Pomerania, basketball games, athletics competitions.

For the first time in 1946, the Recovered Territories Week took place. In the same year, an event on a national scale, not only of a sports nature, but also of great propaganda importance were the Sports Games of the Recovered Territories, held in Szczecin with the participation of Koszalin sportsmen ${ }^{26}$. The representatives of major cities and administrative units of Western and Central Pomerania met in Szczecin. The sporting part of this event was called the First Sports Games of the Recovered Territories. Among sports competitions, the most popular was the football tournament, still volleyball matches, athletics, shooting and boxing matches were also played. As part of the games, a relay was also organized under the slogan Polish wedding with the sea. Its route led from Gdańsk to Szczecin, and 365 competitors started. Among them were members of sports clubs ZWM, OMTUR, scouts and soldiers. The head of the relay was Lt. Col. Stanisław Steczkowski ${ }^{27}$.

Another sporting event was prepared by the organizations dealing with compulsory physical education and sport. On September 14-15, 1946 festival of physical education and military training was organized in Białogard.

The initiator of this event was the commander of the Office of Physical Education and Military Training, Lieutenant Karp-Wośkowiak. He prepared it together with the already numerous group of Białogard activists. The sports program included athletics, team marches, cycling races, football, volleyball and handball tournaments ${ }^{28}$.

\footnotetext{
${ }^{24}$ Szymański A. Sport Słupski 1945-1995. Słupsk, 1996. P. 8.

${ }^{25}$ Cylkowski L. Development of volleyball. P. 32.

${ }^{26}$ Szczerbiński M. Activities of state and social organs of physical culture in the Koszalin region. [in:] B. Woltmann (ed.), Physical culture in the Koszalin region 1945-1990. Koszalin, 1993. P. 22.

${ }_{27}$ Górecki M. The beginnings of post-war physical culture in the Szczecin voivodship in 1945-1950. [in:] B. Woltmann (ed.) Physical culture in the Koszalin region 1945-1989. Koszalin, 1991. P. 73.

${ }^{28}$ Ibid. P. 46.
} 
On the occasion of the celebration of various anniversaries and holidays, among others, in Koszalin, Białogard, Miastko, Złotów, Szczecinek, Wałcz, Kołobrzeg, Słupsk cross-country and street runs were organised and enjoyed great popularity. They were a form of spending free time, but above all a factor integrating the local community. Various professional groups were heavily involved in the organization of these sporting events.

The Civic Militia Training Center (hereinafter: MO) in Słupsk organized a 2,5 km street race, in which 252 competitors from ZZK Ognisko, RKS Elektrocie, OMTUR and Szczecin clubs took part. A 4,5 km street race took place in Wałcz, which gathered 90 participants at the start. The winner was KS Unia Szczecinek, Winand Osiński, Polish senior champion in the marathon, the first Koszalin Olympian from 1952 in Helsinki. In 1948 a new sporting event was inaugurated, which was given the name of the National Race.

In addition to football, volleyball, boxing and street (mass) running, shooting was popular, too. The first shooting championships of West Pomerania were held in Połczyn Zdrój. The event was organized by the Regional Commandant of the WFiPW Office in Sławno, Władysław Orlik and inspectors Romuald Subel from Wałcz and Antoni Kolankiewicz from Sławno ${ }^{29}$.

\section{Organizational Structures of Physical Culture in the Koszalin Region}

Sport was a pleasant way of spending free time, and in a difficult post-war period it was a substitute for normality, it allowed to break away from memories and performed an integrating function. Therefore, apart from organizing sports events, which were a joint celebration, attempts were made to create the first organizational structures, which were sports clubs. They preceded the establishment of state organs and social, managing physical culture, such as, physical education offices, military training and district sports associations.

In the years of 1945-1947, about 40 sports clubs started operating in the Koszalin region. In the first place, sports clubs were established at selected professional groups. The most active activists included railwaymen, militia and craftsmen.

Białogard was a pioneering center of sport. Organized by the Kraków railwayman, activist Władysław Bożątkiewicz, the Unia Sportowy Railway was an organizational model for other PKP nodes of the Szczecin management. The club, whose first president was Stanisław Kopyto, had sections for football, sports games, athletics, shooting, chess, and table tennis ${ }^{30}$. Railway sports clubs were established among organized nodal PKP crews. In July 1945, the Sports Club of the Ognisko Railway Association and the Czarni Railway Sports Club in Słupsk started operating. Its founders were: Józef Goliński, Ryszard Kowalczyk, Jan Sikorski, Józef Kozieł, Tadeusz Srebro - railwaymen delegated from the Krakow management of PKP to organize railways in the western territories $^{31}$. Pioneer sport clubs of railwaymen included: KKS Ognisko Słupsk, KKS Unia Białogard, KKS Jedność Szczecinek. The Workers' Sports Club Electricity Słupsk was also established ${ }^{32}$.

Gwardia sports ${ }^{33}$ clubs were created for larger and larger MO units. National Defense and Home Affairs Ministry and Security was established in Słupsk, which was represented by the MO Training Center club in Stupsk. Its main task was to develop the fitness of young policemen who improved their skills in the sports sections run in the club: football, boxing, athletics, table tennis.

Other clubs were created by activists of the interwar period. Their sponsors were tradesmen, craftsmen, service owners. These included Jantar Ustka, Drawa Drawsko, Sława Sławno, Pionier Człuchów, Bytowia Bytów, Orzeł Wałcz the Crafts Sports Club, Bałtyk Koszalin ${ }^{34}$, which was established on February 25, 1946 in Koszalin and was originally called Naprzód Sports Club.

Eventually, the name was changed to the Baltic Sports Club. Wacław Majerowicz, became the first president. The club ran the football, athletics, sports games tennis and table tennis sections ${ }^{35}$. In the spring of 1946 the club was taken over and modernized by the city stadium.

\footnotetext{
${ }^{29}$ Górecki M. The beginnings of post-war physical culture in the Szczecin voivodship in 1945-1950. [in:] B. Woltmann (ed.): Physical culture in the Koszalin region 1945-1990. Koszalin, 1993. P. 47.

${ }^{30}$ Ibid. P. 43.

${ }^{31}$ Szczerbiński M. Activities of state and social organs of physical culture in the Koszalin region. [in:] B. Woltmann (ed.) Physical culture in the Koszalin region 1945-1989. Koszalin, 1991. P. 30.

${ }^{32}$ Górecki M. The beginnings of post-war physical culture in the Szczecin voivodship in 1945-1950. [in:] B. Woltmann (ed.), Physical culture in the Koszalin region 1945-1990. Koszalin, 1993. P. 42.

${ }^{33}$ Jurek T., Kujawa W. Training staff and sporting activity, [in:] B. Woltmann, Physical culture in the Koszalin region 1945-1990. Koszalin, 1993. P. 35.

${ }^{34}$ Ibid. P. 67.

35 Górecki M. The beginnings of post-war physical culture in the Szczecin voivodship in 1945-1950. [in:] B. Woltmann (ed.), Physical culture in the Koszalin region 1945-1989. Koszalin, 1991. P. 64.
} 
A special role in the organization of sports life in the Koszalin region was played by sports clubs in the Złotów region, which before the war cultivated the traditions of the struggle for the Polishness of these lands, proving the ongoing patriotism and Polishness of the local population. One of them was KS Odra (next known as Sparta) Złotów, which reactivated its activity on May 18, 1945, selecting Henryk Jaroszyk, a well-known Polish community activist, as its president. Then clubs resumed their activity: Orzeł Stawnica, Naprzód Stara Wiśniewka, Jedność Zakrzewo, Sokół Stara Święta and others. Organizational structures of the physical culture and sport in the Koszalin region were developing and undergoing transformation due to changes in the administrative division and the physical culture management system ${ }^{36}$.

Conclusion. It should be noted that until 1945 Central Pomerania belonged to the German State, there were no traditions of the Polish sports movement in this area, and except for the Złotów and Bytów provinces, everything was built from scratch.

After the end of hostilities, the area in question was annexed to Poland, the development and settlement of these lands began, migrants from all over the country came there, including sports activists, athletes and supporters who, using their own experience, founded sports clubs and associations, and decided to develop their favourite disciplines of sports. Sport in this area was more than just competition or «fun for the body and soul», it also served to integrate the settled population. This concerned not only the competitors competing against each other, but also fans watching sporting events that were a joint celebration and allowed to «break away» from memories and difficulties of everyday life in a new place and environment.

To sum up, it is worth noting that the development of physical culture in the area discussed was conditioned by several factors, including the establishment of Koszalin as the capital of the voivodship, which contributed to the grouping of a significant number of Polish troops and internal services in this area. The involvement of professional groups, among others railwaymen, militiamen and craftsmen who came to Koszalin in creating sport life was vital. That sport and sporting events were a substitute for «normality» and pleasure, thanks to which they gathered a large group of supporters, they were able to spend free time, which was conducive to integration, creation of social bonds, which in turn developed mutual acceptance and tolerance for the diversity of environments arrived to the recovered lands, representing their own traditions, customs and culture. Cooperative works for the development of sport formed the foundation of a new social life and creating new communities.

\section{References}

\section{A. Sources}

I. Accounts

An oral account of Adam Krzemiński from 31.07.2019.

B. Studies:

\section{Publications}

1. Czarnik, A. (1970). Koszalińskie - Development of the voivodship in People's Poland. PWN Warsaw.

2. Dunst, M. (ed.) (2006). 60 years of West Pomeranian basketball, ZAPOL Szczecin.

3. Górecki, M. (1991). The beginnings of post-war physical culture in the Szczecin voivodship in 1945-1950/[in:] Woltmann B. (ed.), Physical culture in the Koszalin region 1945-1989, Koszalin.

4. Górecki, M. (1993). The beginnings of post-war physical culture in the Szczecin voivodship in 1945-1950/[in:] Woltmann B. (ed.), Physical culture in the Koszalin region 1945-1990, Koszalin.

5. Jurek, T., Kujawa, W. (1993). Training staff and sports activist. [in:] Woltmann B. (ed.), Physical culture in the Koszalin region 1945-1990. Koszalin.

6. Laskiewicz, H. (1990). Participation in the physical culture of the population of Western Pomerania. US Szczecin.

7. Laskiewicz, H. (1996). Supra-local physical culture organizations in Western Pomerania (1945-1957), US Szczecin.

8. Pasko, A. (2012). Professional sport in state policy 1944-1989, AVALON Kraków.

9. Pawlak, A. (1983). Status of Polish Olympians after the end of their sports careers, Warsaw

10. Połaniecka, A., Jurek, T. (2016). Social range of physical culture in the Stupsk voivodship in the years 19751998, Słupsk.

11. Połaniecka, A. (2017). Sport Stupski in the Stupsk region (1975-1998), Gdańsk, 2017.

12. Rybicki, H., Jędrzejczak, W. (1966). Koszalinskie in the 20 years of the Polish People's Republic. Poznan.

13. Szczerbiński, M. (1991). Activities of state and social organs of physical culture in the Koszalin region/[in:] Woltmann B. (ed.), Physical culture in the Koszalin region 1945-1989, Koszalin.

\footnotetext{
${ }^{36}$ Połaniecka A., Jurek T. Social range of physical culture in the Słupsk voivodship in the years 1975-1998, Słupsk, 2016. P. 36.
} 
14. Szczerbiński, M. (1993). Activities of state and social organs of physical culture in the Koszalin region/[in:] B. Woltmann (ed.), Physical culture in the Koszalin region 1945-1990, Koszalin.

15. Szymański, A. (1996). Sport Stupski 1945-1995. Słupsk.

16. Szwajca, K. (1975). Koszalin lands. Artistic and Graphic Publishing House Krakow.

17. Wilczkowski, E., Pasicznik, W. (2019). Establishment and development of physical education in Asian countries (on the example of China, India, Japan) [in:] E. Małolepszy (ed.), Sport and Tourism Central European Journal of Science, T. 2, NR 3 , Częstochowa.

\section{Unpublished works}

1. Cylkowski, L. (1980). Development of volleyball in the Koszalin province in 1945-1975. Master's thesis, University of Physical Education in Poznań, Branch in Gorzów Wlkp.

2. Rutkowska, Z. (1971). Development of physical culture in the Kolobrzeg Province in 1945-1956. Diploma thesis, Teachers' College in Kołobrzeg.

3. Żytko, T. (1977). Development of handball in the Koszalin Province in 1945-1975. Master's thesis AWF Poznań, Branch in Gorzów Wielkopolski Gorzów.

Стаття надійшла до редакції 01.10.2019 p. 